\title{
ANALISIS TANGGUNG JAWAB SUAMI TERHADAP ISTRI DAN ANAK PASCACERAI TALAK DI PENGADILAN AGAMA KLATEN
}

\author{
Dinda Berliana Kusumawardani \\ E-mail: Dindaberlianaa@yahoo.com \\ Mahasiswa Fakultas Hukum Universitas Sebelas Maret \\ Pranoto \\ E-mail: Maspran7@gmail.com \\ Dosen Fakultas Hukum Universitas Sebelas Maret
}

\begin{abstract}
The writing of this law aims to examine the responsibility of the husband towards his wife and children after divorce divorce. Divorce does not mean the release of the husband's responsibility to give responsibility to the ex-wife whether iddah, mut'ah, and child income, with conditions according to the ability of the husband. This legal research uses prescriptive empirical legal research. The approach taken with the statutory approach, primary legal materials used in primary law in the form of legislation relating to the husband's responsibility between divorce divorce and divorce and secondary legal materials used in the form of legal books and legal research are relevant. The legal material collection techniques used include documentary studies and direct interviews with Religious Court Judges in Klaten. Legal material analysis technique uses analytical techniques that are educational by the method of sociology.
\end{abstract}

Keywords: Talak Divorce; Husband's Responsibility; Wife and Child Income

\begin{abstract}
Abstrak
Penulisan hukum ini bertujuan untuk mengkaji mengenai tanggung jawab suami terhadap istri dan anak pascacerai talak. Adanya perceraian bukan berarti lepasnya tanggung jawab suami untuk memberikan tanggung jawab kepada mantan istri baik itu nafkah iddah, mut'ah, dan nafkah anak, dengan syarat sesuai dengan kemampuan suami. Penelitian hukum ini menggunakan penelitian hukum Empiris yang bersifat preskriptif. Pendekatan yang dilakukan dengan pendekatan perundang-undangan, bahan hukum primer yang digunakan dalam hukum primer ini berupa peraturan perundang-undangan yang berkaitan dengan tanggung jawab suami antara cerai talak dan cerai gugat serta bahan hukum sekunder yang digunakan berupa buku-buku hukum dan penelitian hukum yang relevan. Teknik pengumpulan bahan hukum yang digunakan meliputi studi dokumenter dan wawancara secara langsung dengan Hakim Pengadilan Agama di Klaten. Teknik analisis bahan hukum menggunakan teknik analisis yang bersifat deduksi dengan metode silogisme.
\end{abstract}

Kata Kunci: Cerai-Talak; Tanggung Jawab Suami; Nafkah Istri dan Anak

\section{A. Pendahuluan}

Manusia adalah pada hakikatnya sebagai makhluk sosial. Allah SWT menciptakan manusia untuk hidup berpasang-pasangan dan Allah mengkaruniai manusia dengan perasaan cinta kasih, hawa nafsu, serta akal pikiran. Disamping itu fitrah manusia adalah sebagai makhluk sosial membuatnya tidak mampu untuk hidup sendiri, oleh Karena itu Allah menetapkan dengan suatu ikatan suci yang disebut pernikahan. Adapun masalah perceraian dalam Hukum Indonesia diatur dalam Undang-Undang No. 1 Tahun 1974 tentang perkawinan, yaitu pada pasal 38 yang berbunyi : perkawinan dapat putus dikarenakan kematian, perceraian dan atas putusan pengadilan. Di Indonesia kasus perceraian mulai meningkat setiap tahunnya. Dalam empat tahun terakhir perceraian di Indonesia meningkat tajam, dari rata-rata 20.000 kasus pada tahun 2004 menjadi 200.000 kasus perceraian pada tahun 2008 dari 2 juta pernikahan yang ada. Angka perceraiaan di setiap daerahpun tiap tahunnya juga mengalami peningkatan, di Pengadilan Agama Klaten 
dari bulan Januari - Juli 2019 sudah tercatat ada sebanyak 1.169 gugatan perceraian. Jumlah perceraian yang meningkat ini memiliki beberapa faktor penyebab. Menurut Nasrudin Umar, dari hasil penelitian Departemen Agama terdapat 14 faktor yang menjadi penyebab perceraian, yakni: faktor suami atau istri tidak bertanggung jawab, ekonomi, imigrasi, KDRT, selingkuh, cacat, sakit, jarak, ketidakcocokan, perkawinan di bawah umur, perbedaan intelektual, dan faktor politik. (http://m.solopos.com/2-hal-ini-jadi-penyebab-utama-perceraian-pasutri-di-klaten-1010444). diakses pada tanggal 28 Oktober 2019.

Dari beberapa faktor perceraian tersebut, yang paling sering menjadi pemicu perceraian yaitu faktor ekonomi. Ekonomi keluarga yang rendah dapat menimbulkan beberapa permasalahan seperti perselisihan dalam rumah tangga, KDRT, perselingkuhan, dan suami melalaikan tugas dan tanggung jawabnya. Tugas seorang suami dalam keluarga adalah memberikan nafkah kepada istri dan anak. Suami adalah seorang pemimpin bagi keluarganya, sehingga suami memiliki tanggung jawab yang penuh pada keluarganya. Menurut, (Dinata, 2016: 18), seorang suami berkewajiban untuk memberikan nafkah kepada istri dan anaknya serta menyediakan tempat tinggal sesuai dengan kadar kesanggupannya. Apabila seorang suami tidak mampu memberikan nafkah terhadap istri dan anaknya, maka hal itu akan menjadi salah satu penyebab terjadinya perceraian. Menurut Ramulyo, jatuhnya talak, baik cerai talak maupun cerai gugat dianggap terjadi sejak jatuhnya putusan pengadilan agama yang telah mempunyai kekuatan hukum yang tetap. Jatuhnya putusan pengadilan menyangkut tentang tanggung jawab suami terhadap istri dan anak setelah terjadi perceraian. Hal ini sesuai dengan Undang-Undang Nomor 1 Tahun 1974 Pasal 45 Ayat 1 berisi tentang perkawinan, mengenai hak dan kewajiban antara orang tua dan anak dalam bukunya (Ahmad Azhar, 2014:112) yaitu :

"kedua orang tua wajib memelihara dan mendidik anak-anak mereka sebaik-baiknya."

Sedangkan ayat (2) yaitu:

"kewajiban orang tua yang dimaksudkan dalam ayat (1) berlaku sampai anak itu kawin atau dapat berdiri sendiri. Kewajibannya berlaku terus meskipun perkawinan antar keduanya putus".

Menurut ketentuan dua ayat itu dapat disimpulkan bahwa memelihara dan mendidik anak menjadi kewajiban bersama antara ibu dan bapak, berlaku sampai anak telah kawin atau dapat berdiri sendiri, meskipun bapak ibu yang bersangkutan mengalami perceraian. Hal ini sesuai dengan Pasal 24 Ayat 2 bahwa jika selama berlangsungnya gugatan perceraian suami harus memberikan nafkah sesuai dengan ketentuan pengadilan, menjamin pemeliharan dan pendidikan anak, menjamin terpeliharanya barang-barang yang menjadi hak bersama suami istri atau barangbarang yang menjadi hak suami atau barang- barang yang menjadi hak istri. (Latif, 1982:111)

Berdasarkan uraian di atas maka artikel ini akan membahas tentang analisis tanggung jawab suami terhadap istri dan anak pascacerai talak di Pengadilan Agama Klaten.

\section{B. Metode Penelitian}

Penelitian ini menggunakan jenis penelitian empiris, sebab dari judul yang diangkat mengacu kepada bentuk perlindungan hukum tentang tanggung jawab suami terhadap istri dan anak antara talak cerai dan talak gugat yang ditinjau dalam Undang-Undang No. 1 Tahun 1974 Pasal 41. Penelitian empiris adalah penelitian hukum positif tidak tertulis mengenai perilaku anggota masyarakat dalam hubungan hidup bermasyarakat (Abdul kadir, 2004:155). Atau dengan kata lain menurut (Bambang Waluyo, 2002:16) yaitu suatu penelitian yang dilakukan terhadap keadaan sebenarnya atau keadaan nyata yang terjadi di masyarakat dengan maksud untuk mengetahui dan menemukan fakta dan data yang dibutuhkan, setelah data yang dibutuhkan terkumpul kemudian menuju kepada identifikasi masalah yang pada akhirnya menuju pada penyelesaian masalah. 


\section{Hasil Penelitian dan Pembahasan}

1. Data cerai talak di Pengadilan Agama Klaten

a. Permohonan cerai talak yang telah didaftarkan di Kepaniteraan

Pengadilan Agama Klaten, dengan Nomor Register 0535/Pdt.G/PA.KIt, tanggal 01 April 2019. Pengajuan cerai talak di atas disebabkan karena:

1) Termohon mudah marah-marah hanya karena masalah sepele dan sering membesarbesarkan masalah kecil;

2) Termohon sering merasa kurang atas pemberian nafkah dari Pemohon padahal Pemohon sudah berusaha memberikan nafkah sesuai dengan kemampuan Pemohon;

3) Apabila terjadi perselisihan atau pertengkaran antara Pemohon dan Termohon, anak Termohon dari pernikahan Termohon dahulu sering ikut campur bahkan pernah mengancam Pemohon dengan menggunakan senjata tajam;

4) Antara Pemohon dan Termohon terus menerus terjadi perselisihan dan pertengkaran, dan tidak ada lagi kecocokan untuk hidup bersama dalam rumah tangga;

Berdasarkan permasalahan tersebut di atas maka Majelis Hakim berkesimpulan bahwa karena Permohonan Permohon tersebut beralasan serta telah terbukti menurut hakim maka permohonan Pemohon dapat dikabulkan, oleh karena itu hakim memutuskan:

1. Mengabulkan Permohonan Pemohon, hal ini didasarkan karena fakta- fakta hukum bahwa rumah tangga antara Pemohon dan Termohon sudah tidak harmonis lagi, sehingga telah memenuhi alasan perceraian menurut hukum sebagaimana ketentuan pasal 19 huruf f Peraturan Pemerintah Nomor 9 Tahun 1975 jo Pasal 116 huruf f KHI.

2. Memberikan Izin kepada Pemohon untuk menjatuhkan talak satu raj'i kepada Termohon sesuai maksud ketentuan Pasal 70 ayat (1) Undang-Undang Nomor 7 Tahun 1989 tentang Peradilan Agama yang telah diubah dengan Undang-Undang Nomor 3 Tahun 2006 dan perubahan kedua dengan Undang-Undang Nomor 50 Tahun 2009 jo Pasal 118 dan Pasal 131 ayat (2) KHI.

3. Menghukum Pemohon memberikan kepada Termohon setelah ikrar Talak diucapkan berupa:

1) Mut'ah berupa uang sejumlah Rp. 500.000,- (Lima ratus ribu rupiah);

2) Nafkah selama masa iddah sejumlah Rp. 1.500.000,- (Satu juta lima ratus ribu rupiah)

3) Membebankan kepada Pemohon untuk membayar biaya perkara sejumlah Rp. 456.000,- (Empat ratus lima puluh enam ribu rupiah). Dikarenakan hal ini termasuk dalam bidang perkawinan maka sesuai ketentuan pasal 89 ayat (1) Undang-Undang Nomor 7 Tahun 1989 tentang Peradilan Agama yang telah diubah dengan Undang-Undang Nomor 50 Tahun 2009.

b. Pengajuan permohonan Cerai Talak yang telah didaftarkan di Kepaniteraan Pengadilan Agama Klaten, dengan Nomor Register 1496/Pdt.G/2018/PA.KIt, tanggal 25 September 2018. Pengajuan cerai talak diatas disebabkan karena:

1) Mengalami ketidakharmonisan dalam rumah tangga yakni Termohon susah diatur oleh pemohon dalam segala hal, salah satunya disebabkan karena dahulu Pemohon menganjurkan kepada Termohon untuk keluar dari tempat kerja Termohon yang masih berkaitan dengan riba namun hal tersebut ditolak oleh Termohon tanpa alasan yang jelas.

2) Termohon selalu menolak ajakan Pemohon untuk hidup bersama dengan pemohon dan malah meminta kepada Pemohon untuk menceraikan Termohon dan tidak ada harapan akan hidup rukun Igi dalam rumah tangga. 
3) Termohon pergi meninggalkan Pemohon tanpa sepengetahuan dari Pemohon sampai sekarang sudah berlangsung selama 3 tahun 7 bulan dan selama itu diantara Pemohon dan Termohon sudah tidak ada komunikasi lagi.

Berdasarkan permasalahan tersebut di atas maka Majelis Hakim berkesimpulan bahwa karena Permohonan Permohon tersebut beralasan serta telah terbukti menurut hakim maka permohonan Pemohon dapat dikabulkan, oleh karena itu hakim memutuskan:

1. Dalam Konvensi:

a) Mengabulkan permohonan Pemohon, hal ini didasarkan karena faktafakta hukum bahwa rumah tangga antara Pemohon dan Termohon sudah tidak harmonis lagi, sehingga telah memenuhi alasan perceraian menurut hukum sebagaimana ketentuan pasal 19 huruf f Peraturan Pemerintah Nomor 9 Tahun 1975 jo Pasal 116 huruf $f \mathrm{KHI}$.

b) Memberikan izin kepada Pemohon untuk menjatuhkan talak raj'i terhadap Termohon di depan sidang Pengadilan gama Klaten, sesuai maksud ketentuan Pasal 70 ayat (1) Undang-Undang Nomor 7 Tahun 1989 tentang Peradilan Agama yang telah diubah dengan Undang- Undang Nomor 3 Tahun 2006 dan perubahan kedua dengan Undang- Undang Nomor 50 Tahun 2009 jo Pasal 118 dan Pasal 131 ayat (2) KHI.

2. Dalam Rekonvensi:

a) Mengabulkan gugatan Rekonvensi sebagian:

b) Menghukum Tergugat Rekonvensi memberikan kepada Penggugat Rekonvensi setelah ikrar Talak diucapkan berupa:

c) Mut'ah berupa cincin emas seberat 2 gram;

d) Nafkah selama dalam iddah sejumlah Rp. 1.500.000,- (Satu juta limaratus ribu rupiah);

e) Menetapkan anak Penggugat Rekonvensi dan Tergugat Rekonvensi berada dalam pemeliharaan/hak hadhonah Penggugat Rekonvensi selaku ibu kandungnya sesuai dengan ketentuan Pasal 105 huruf a dan Pasal 156 huruf a $\mathrm{KHI}$, dengan tetap memberikan akses kepada Tergugat Rekonvensi selaku ayah kandungnya untuk dapat bertemu atau berkunjung dan mencurahkan kasih sayang kepada kedua anaknya tersebut selama tidak mengganggu pendidikan anak;

f) Menghukum Tergugat Rekonvensi memberikan biaya pemeliharaan anak tersebut pada dictum angka 3 setiap bulan minimal Rp.500.000,- (Lima ratus ribu rupiah) sampai anak kawin atau berusia 21 tahun, atau dapat berdiri sendiri, dibiarkan melalui Penggugat Rekonvensi selaku ibu kandung.

g) Menolak gugatan Penggugat Rekonvensi selebihnya;

h) Membebankan kepada Pemohon Konvensi/Tergugat Rekonvensi untuk membayar biaya perkara ini sejumlah Rp. 391.000,- (Tiga ratus Sembilan puluh satu ribu rupiah). Dikarenakan hal ini termasuk dalam bidang perkawinan maka sesuai ketentuan pasal 89 ayat (1) Undang-Undang Nomor 7 Tahun 1989 tentang Peradilan Agama yang telah diubah dengan Undang-Undang Nomor 50 Tahun 2009.

2. Analisis Tanggung jawab suami terhadap Istri dan anak pascacerai talak di Pengadilan Agama Klaten.

Cerai talak dibagi menjadi tiga menurut (Ahmad Zacky,113-114), yaitu talak wajib, haram dan sunnah. Talak wajib merupakan talak yang dijatuhkan oleh dua orang hakam (penengah), karena terjadinya pertikaian dan perpecahan di antara suami dan istri yang 
sudah tidak dapat disatukan kembali. Talak haram adalah talak yang dijatuhkan tanpa sebab dan alasan yang jelas, sehingga merugikan salah satu pihak. Talak sunnah adalah talak yang diajukan oleh seorang suami terhadap istri ketika rumah tangga sudah tidak dapat dipersatukan kembali, yang diakibatkan karena istri mengabaikan kewajibannya kepada Allah SWT, seperti halnya pada Pengadilan Agama Klaten menyebutkan bahwa Termohon mudah marah hanya karena masalah kecil dan sering membesar-besarkan masalah kecil; Termohon sering merasa kurang atas pemberian nafkah dari Pemohon padahal Pemohon sudah berusaha memberikan nafkah sesuai dengan kemampuan Pemohon; Antara Pemohon dan Termohon terus menerus terjadi perselisihan dan pertengkaran, dan tidak ada lagi kecocokan untuk hidup bersama dalam rumah tangga; Termohon susah diatur oleh Pemohon dalam segala hal; Termohon pergi meninggalkan Pemohon tanpa sepengetahuan dari Pemohon

Pada data penelitian di Pengadilan Agama Klaten disebutkan bahwa jika seorang istri tidak dapat melaksanakan tugas sebagaimana mestinya menjadi seorang istri maka suami berhak mengajukan permohonan cerai talak dapat terjadi apabila suami mengajukan permohonan. Dasar hukum cerai talak pada Pengadilan Agama Klaten merujuk pada Pasal $121 \mathrm{HIR}$. Penggunaan pasal $121 \mathrm{HIR}$ sebagai dasar hukum cerai talak dikarenakan dengan adanya penetapan biaya perkara sesudah surat permohonan dibuat dan didaftarkan oleh panitera di dalam daftar yang telah disediakan, untuk itu maka ketua menentukan hari dan jam, waktu perkara itu akan diperiksa di muka Pengadilan. (Teuku Abdul Manan, 2018:51). Penetapan biaya yang dilakukan oleh pengadilan agama merupakan cara mengadili perkara pada tingkat pertama dalam Sidang Majelis dalam menjatuhkan putusan perkara Cerai Talak. Jatuhnya putusan Cerai Talak yang diberikan oleh Mjaelis Hakim didasarkan atas pertimbangan-pertimbangan yang memenuhi alasan perceraian menurut hukum, hal ini sesuai dengan ketentuan Pasal 70 ayat (1) Undang- Undang Nomer 7 Tahun 1989 tentang Peradilan Agama yang telah diubah dengan Undang-Undang Nomer 3 Tahun 2006 dan perubahan kedua dengan Undang-Undang Nomer 50 Tahun 2009 jo Pasal 118 dan Pasal 131 ayat (2) KHI, bahwa petitum permohonan Pemohon agar diberikan izin untuk menjatuhkan talak terhadap Termohon dapat dikabulkan, dengan biaya perkara yang dibebankan kepada Pemohon.

Pada dasarnya yang menjadi kekuatan hukum tetap pada perkara cerai talak adalah pembacaan ikrar Talak. Pembacaan ikrar Talak dilakukan setelah hakim membacakan putusan sebagaimana yang diatur dalam Pasal 66 ayat (1) Undang-Undang Nomor 7 tahun 1989, setelah ikrar talak dibacakan mantan istri berhak mendapatkan nafkah sesuai yang diminta sebagaimana telah diatur dalam Pasal 66 ayat (5) Undang-Undang Nomor 7 tahun 1989. Mut'ah dan nafkah iddah merupakan kewajiban mantan suami kepada mantan istri yang telah diceraikan. Hal ini merupakan suatu sikap yang sepatutnya dilakukan oleh suami karena suami berkeinginan untuk bercerai atau putus perkawinan dengan istrinya, Sehingga sebagai bentuk tanggung jawab walaupun belum cukup sebagai pengobat kecewa, akan tetapi mut'ah dan nafkah iddah bisa meringankan beban mantan istri. Mantan istri bisa mendapatkan nafkah iddah selama tidak nusyuz, istri yang tergolong nusyuz dan yang qabla dakhul tidak dapat mendapatkan nafkah iddah.

3. Dasar Hukum pertimbangan Hakim dalam memutuskan perkara Cerai Talak

Cerai Talak dapat terjadi apabila suami mengajukan permohonan. Suami yang merasa haknya dilanggar dia yang berhak mengajukan gugatan. Apabila suami haknya dilanggar dan sudah tidak dapat dipersatukan kembali, maka suami diperbolehkan mengajukan permohonan cerai. hal ini dipertegas dengan pendapat Majelis Hakim Ahmad Wahib bahwa Dasar hukum cerai talak pada Pengadilan Agama Klaten Pasal $121 \mathrm{HIR}$.

Menurut pendapat Majelis Hakim Pengadilan Agama Klaten Bapak Ahmad Wahib mengatakan bahwa pemberian nafkah iddah diberikan setelah penyaksian ikrar talak yang dilakukan oleh suami karena pada dasarnya massa iddah jatuh setelah suami menjatuhkan talak kepada istrinya. Pada perkara cerai talak yang menjadi putusan berkekuatan hukum tetap adalah setelah suami membacakan ikrar talak. Sedangkan mut'ah adalah pemberian 
suami kepada mantan istri yang sudah dijatuhi talak baik berupa uang atau benda. Alasan Majelis Hakim memerintahkan mantan suami memberikan nafkah baik iddah ataupun mut'ah karena sebagai langkah untuk menegakkan hukum dan memperjuangkan hak istri yang harus dipenuhi oleh mantan suami. Majelis Hakim juga mengatakan bahwa kewajiban suami setelah perceraian dengan anak istri nafkah lampau atau nafkah madyah juga perlu dibayarkan. Apabila saat proses perceraian istri menyampaikan bahwa istri tidak diberikan nafkah dan telah pisah rumah, berhak mengajukan tuntutan. Besarnya nafkah pasca perceraian ditentukan oleh hakim dan biasanya besarnya nafkah adalah separuh dari nafkah yang diberikan ketika menjadi istri sah. Untuk Hak anak atau nafkah anak Suami berkewajiban memberikan nafkah kepada anak pada masa yang akan datang, dan sistem penuntutannya setiap bulan sampai anak tersebut berumur 21 tahun atau sudah dewasa. kemudian beliau juga mengatakan bahwa Proses dan syarat-syarat Untuk mengajukan perceraian lebih rumit cerai talak dibandingkan dengan cerai gugat dan biaya lebih mahal.

\section{Simpulan}

Analisis tanggung jawab suami terhadap istri dan anak pascacerai talak di Pengadilan Agama Klaten mantan istri menerima nafkah berupa mut'ah, nafkah iddah, nafkah madhiyah, dan untuk hak anak atau nafkah anak Suami berkewajiban memberikan nafkah kepada anak pada masa yang akan datang, dan sistem penuntutannya setiap bulan sampai anak tersebut berumur 21 tahun atau sudah dewasa. kebijakan tersebut dilakukan untuk memberikan keadilan bagi istri yang ditalak oleh suaminya.

\section{E. Saran}

1. Hendaknya hakim memerintahkan suami yang menceraikan istrinya hendaknya memberikan mut'ah, nafkah iddah, dan nafkah madhiyah meskipun istri tidak mengajukan rekonvensi. Nafkah tersebut digunakan untuk biaya hidup istri dan anaknya, terlebih jika istri tidak mempunyai biaya.

2. Hendaknya Pemerintah bersama DPR membuat suatu peraturan perundang-undangan mengenai batasan waktu pembayaran mut'ah, nafkah iddah, dan nafkah madhiyah serta peraturan sanksi hukum bagi suami yang tidak mau membayar kewajibannya, agar dapat memberikan keadilan dan jaminan hak-hak istri yang diceraikan oleh suaminya.

\section{F. Daftar Pustaka}

\section{Buku:}

Abdul Kadir Muhamad .2004. Hukum dan Penelitian Hukum. Bandung: PT Citra Aditya Bakti Arda dinata 2016. Pernikahan berkalung pahala. Jakarta: PT Elex Media Komputindo

Azizah,dan kawan-kawan. 2018. Ketahanan Keluarga dalam Perspektif Islam. Jakarta: Pustaka cendekiawan muda

Bambang Waluyo.2002. Penelitian Hukum dalam Praktek. Jakarta: SinarGrafika.

Endra Muhadi. 2019. Aspek-Aspek Maqasid Asy-Syari'ah dalam Penetapan Alasan-Alasan Perceraian. Yogyakarta. Stiletto inde book

H.M Djamil Latif. 1982. Aneka Hukum Perceraian di Indonesia. Ghalia Indonesia. Jakarta.

KH. Ahmad Azhar Basyir. 2014. Hukum Perkawinan Islam. UII Pres Yogyakarta. Yogyakarta. Muh. Idris Ramulyo.1999. Hukum Perkawinan Islam. Jakarta : Bumi Aksara 
Mukti Fajar dan Yulianto Achmad, 2017. Dualisme Penelitian Hukum Normatif dan Empiris, Cetakan IV. Yogyakarta: Pustaka Pelajar

\section{Jurnal}

Syaiful Annas. 2017."Masa Pembayaran Beban Nafkah Iddah dan Mut'ah dalam Perkara Cerai Talak (Sebuah Implementasi Hukum Acara di Pengadilan Agama) Syaiful Annas Pengadilan Agama Batulicin, Tanah Bumbu, Kalimantan Selatan." Al- Ahwal: Jurnal Hukum Keluarga Islam. Volume 10, Nomor 1. Yogyakarta : Universitas Islam Negeri Sunan Kalijaga Yogyakarta

Oyoh Bariah. 2018. "Analisis Putusan Pengadilan Agama Karawang tentang Cerai Gugat karena Pelanggaran Taklik Talak (studi perkara No 0554/Pdt G.2015/PA.Krw)". Journal for Islamic Studies. Volume 1 Nomor 1. Bandung: Asosiasi Dosen DPK UIN Sunan Gunung Djati Bandung

Muchammad Hammad. 2016." Hak-hak perempuan pascaperceraian: nafkah iddah talak dalam hukum keluarga muslim Indonesia, Malaysia, dan Yordania ". Jurnal Hukum Keluarga Islam. Volume 7 Nomor. Yogyakrta : Universitas Islam Negeri Sunan Kalijaga Yogyakarta

\section{Internet:}

(http://m.solopos.com/2-hal-ini-jadi-penyebab-utama-perceraian-pasutri-di-klaten-1010444).

\section{Wawancara:}

Majelis Hakim di Pengadilan Agama Klaten Bapak Drs. Ahmad Wahib S.H., M.H

Panitera Muda di Pengadilan Agama Klaten Ibu Uswatun Hasanah S.H 